\title{
Library Education in the Soviet Union
}

TN JUNE of 1956 when a class from the 1 library school of the Stockholm City Library visited the Soviet Union on a study trip, its members quite naturally tried to learn something about Russian library education. This article* is a report on what we. learned together with some information derived from other sources.

Of course, library education existed in pre-revolutionary Russia even though it was not very extensive. For example, starting in 1913 the university for adult education in Moscow taught courses in library science. However, it was only after the October Revolution that the importance of libraries and, therefore, of library education was fully recognized; and, of course, principally as a propaganda instrument for the new form of government. According to Steiner, "Those who had newly come to power wished to create a network of libraries of all kinds throughout the entire Union and to develop and spread new working methods which would serve to educate the masses in communism and to build up a socialistic culture, science and technical facility." From the very beginning of the formation of the new Soviet state, Lenin and Stalin turned their attention to the organization of libraries. N. K. Krupskaya, Lenin's wife, was at that time the leader of the Soviet library system. On November 3,1920 , a decree was issued which

* Published originally in Swedish in Biblioteksbladet, IX (1957). It is reprinted here with the author's permission. Translated by Thomas R. Buckman, Head, Acquisitions Department, University of Kansas Libraries, Lawrence.

Valter Ahlstedt is Assistant Librarian of the Stockholm Public Library. provided the organizational basis for the development of the library system. A few figures show what enormous prog. ress was made: In 1914 there were 12,600 public libraries and in 1939 there were 250,000 libraries of all kinds, of which 77,600 were public libraries. In 1956, according to information given to us on our trip, there were 390,000 libraries of all types in the Soviet Union.

Because of this expansion, education for librarianship became an important question. At first, library departments were established in some communistic higher schools, pedagogical institutes, and political schools. Between the years 1925-30 there were also nine-year schools in which students were prepared for library work in their final two years. Library courses on a higher level were held for many years at the SaltykovShchedrin Library in Leningrad and in the Lenin Library in Moscow. A decree from the year 1934 regarding the library system in the Soviet Union introduced a new phase in library education.

At present, education for librarianship takes three forms in the Soviet Union: studies in a library technical school, in a library institute, and in continuation courses as an aspirant.

The library technical school, as the name implies, teaches basic subjects in library science and prepares its students for junior positions in city, district, and children's libraries. These basic schools are spread over the entire country (in 1952 there were twenty-five of them in Russia itself, sixteen in the Ukraine, etc.). Previously, after seven years of elementary school, students would be accepted at the library tech- 
nical school (at an age of about fourteen years) where they would study for three years. According to the information we were given however, a ten-year elementary course is now required for entrance. The length of the training is now one and a half years, but it is planned to increase it to two years. In these basic library technical schools the students study, as required subjects, the history of the Soviet Union and modern history in general, the Russian language, literature, mathematics, physics, natural science, economic geography, chemistry, one foreign language, library history and library organization, bibliography, techniques of library science, organization of work, and reference service. Elective subjects are the methods of reading fiction, and advertising techniques.

During the school year $1945-46,4,500$ students received their training at these schools, and in 1951, 11,000. Starting in 1949 the theoretical training was combined with practice at a district or rural library. In the practice work greatest emphasis is placed on giving advice to readers and in trying to stimulate reading interests.

The library institute is intended for higher professional education. Library directors, bibliographers, library school lecturers, and library supervisors receive their training here. At present there are two such institutes in the Soviet Union, one in Moscow and the other in Leningrad. Of equal rank with these are the library school faculties at the pedagogical institutes in Kharkov, Minsk and Tiflis. Entrance requirements are completion of ten years of elementary school and an admission examination in Russian language and literature, history, geography and one foreign language; however, if the candidates were high in their classes in the elementary school the admission examination is waived. At the time of entrance the students are about seventeen years of age. Through an interview the director of the school attempts to determine the suitability of the students. He may advise a student not to enter, but cannot forbid him to do so. The length of the course is four years.

During our trip we had an opportunity to study the library institutes in Leningrad and Moscow.

The Leningrad institute which is located in a former embassy palace on the Neva Embankment was founded in 1918 and was the first Soviet higher school especially intended for the education of librarians. In the beginning it was a part of the pedagogical faculty at the university, but since 1941 it has been an independent school, in continuous operation excepting during the war years 1941-44. Each year 210 students are admitted and, in addition, 60 students who wish to be trained as children's librarians. Besides there is an evening course for those who are already employed in a library ( 60 persons are enrolled), and a correspondence course with 400 persons enrolled. A director is in charge of the school, and an assistant director is responsible for matters relating to study and research, administration, instruction by correspondence, and evening courses. The institute has two faculties each with its dean, one for the general division and one for the division concerned with the training of children's librarians. There are nine faculty positions three of which are in the special subjects: library science, bibliography, and library work with children. Each subject has its own seminar library with course books in many copies. In all there are 120,000 volumes. The book stock seemed to be poorly cared for and the catalogs were unsatisfactory. Foreign bibliographies were entirely lacking. Since the end of the war some two thousand students have been graduated from the institute.

The Moscow institute, which is lo- 
cated about eighteen miles from the center of the city, was founded in 1930. It is divided into two departments, one for the education of librarians and the other for teachers who will work in adult education. The latter department trains leaders for clubs and cultural centers. It has been in existence only a couple of years. In the day division there are 1,300 students, in the evening division 500 and in the correspondence division, 2,600. The institute is a boarding school somewhat similar to the Scandinavian folk high schools. About half of the students live at the school in especially provided dormitories. About six thousand students have been graduated from the institute.

The instruction of the library institutes, which consists of lectures, seminars, and practical exercises, includes three kinds of subjects:

1. General subjects. Under this heading the following are included: sociology, economics, philosophy, Marxism, history, history of literature, one foreign language (German, English or French), pedagogy, psychology, fundamentals of industrial and agricultural production, gymnastics and physical education. These courses occupy two-thirds of a student's total period of study at the institute.

2. Special subjects. These include library history (Russian and foreign), library science (including administration, book selection, and cataloging), bibliography (general and special), subject literature (principally in the social sciences, agriculture and industry), and library work with children.

3. Optional courses. For example, picture collections, advertising, the history of art, music and theatre. Those who wish to become children's librarians may choose public speaking, oral interpretation, story telling, club activity, etc.

During the four years of study the students have seventeen weeks of prac- tical library experience. In the second year they do practice work at a large library and are concerned especially with cataloging and the book collection. During the third year they work seven weeks at a district library which contains from two to three hundred thousand volumes and devote themselves principally to reference and circulation work. Finally, during the fourth year they serve in one of the smaller rural libraries or in a branch of a city library and spend most of their time in studying methods and supervision.

Written assignments must also be completed during the course of study. During the second year a report on a book dealing with cataloging is required, during the third year a bibliography in an assigned subject must be compiled and defended, and during the fourth, a similar bibliography is made, but on an optional subject.

The examinations are taken successively in the various subjects. (Students taking the correspondence course may be examined in the general subjects at the institute and, if they pass, their fares will be paid by the institute. The examinations may also be taken at local colleges.) The final examination is given by members of a state commission and include three subjects: Marxism, history of literature, and library science. The examiners are experts from the Ministry of Education. The period of the examination is ten days. At the time of our visit to the library institute in Moscow the final examinations in library science were being held and we had the opportunity of hearing a part of the oral questioning. The examinee was required, with the help of a few notes, to give short extemporaneous talks on two library subjects.

Students with good grades are eligible, during the period of study, for stipends which in Leningrad amount to 220-390 rubles per month, and in Mos- 
cow, 250-295 rubles per month. Those with the highest grades may receive an additional 25 per cent. Personal stipends from 400 to 700 rubles a month are also available from labor unions and other sources.

When the course is completed the Ministry of Instruction assigns positions to the newly graduated librarians, which they must occupy for a period of three years. The wishes of the students and their places of residence are taken into consideration in making the assignments. Many of the new librarians regard themselves as pioneers and request that they be sent to remote places.

The library institutes provide graduates chiefly for the public libraries, but in Moscow, for example, about two hundred of the students had been given positions at the Lenin Library. Salaries range from 500 to 1,500 rubles. However, those with advanced academic degrees receive 2,400 rubles, and librarians in the academies of science receive a salary of 3,000 rubles. Librarians who have a good knowledge of one foreign language receive an additional increment of 10 per cent.

Students who have shown an aptitude for research may continue their library studies after taking the examination at one of the institutes. Such students may obtain an aspirant's appointment for a period of three years (four years, if the student is engaged in part-time work of some kind). These appointments correspond to American graduate scholarships or fellowships. Aspirants receive 680 rubles per month for subsistence and 680 rubles per year for books. During the period of study a paper must be written which must be publicly defended at the institute in the presence of three opponents. The students who are successful receive the title of Candidate in Pedagogy with library science or bibliography as their major subject. At the next level is the doctor's degree in library science which is granted only by the faculties of pedagogy at the universities. It should also be mentioned that the scholarly libraries such as, for example, the Lenin Library, give one-year courses for their staff members who have had a college or university education. These courses are designed to train special librarians.

Steiner has characterized the goal of Soviet librarianship in this way: "We must train librarians who have a thorough knowledge of the fundamentals of Marxism and Leninism, who have a good general education, who are well acquainted with the library system, who know books and the methods which are used in work with books, and who are capable of carrying out communistic educational work among the masses." This goal reveals both the strength and the weakness in Soviet education for librarianship. The weakness from our point of view is of course the ideological and national limitation. The strength is the positive interest in the library system shown by the state and its awareness of the importance of libraries in society. On the credit side should also be noted the enthusiasm and pioneering spirit of the young librarians-to-be and their zeal for making a contribution wherever they are placed.

\section{REFERENCES}

K. Knutsson, "Folkbibliotek i Sovjetunionen," Biblioteksbladet, XXXIII (1948), 5459.

W. Saxtorph, "SSSR-Borgernes Adgang til at lâne Bøger," Salmonsen Leksikon-Tidsskrift, XIII (1933), 159-64.

G. Steiner, "Die bibliothekarische Ausbildung in der Sowjetunion," Der Bibliothekar, VI (1952), 138-43.

[EDIToR's Note: It has been suggested that readers of this article also would be interested in examining another paper on Soviet library education. This is Horst Kunze, "Ausbildung," Zentralblatt fur Bibliothekswesen, LXXI (1957), 134-38.] 